\title{
Jeugdrechtmodellen in de Belgische wet en beslissingspraktijk in jeugdstrafzaken
}

\author{
Jolande uit Beijerse
}

Goedseels, E. (2015). Jeugdrechtmodellen in theorie en praktijk. Een empirisch onderzoek naar het discours en de praktijk van Belgische jeugdrechters (dissertatie KU Leuven).

'Door welke jeugdrechtmodellen laat de dagelijkse beslissingspraktijk van Belgische jeugdrechters zich kenmerken?', dat is de vraag die de Belgische criminologe Eef Goedseels zich in haar dissertatie stelt. Die vraag is uitgewerkt in een goed gestructureerd en zorgvuldig uitgevoerd onderzoek dat zowel criminologen als juristen de nodige stof tot nadenken geeft. Hoewel het om een onderzoek gaat naar de Belgische wet en praktijk, zijn de uitkomsten daarvan ook interessant voor Nederlandse wetenschappers, beleidsmakers en professionals die zich met het jeugdstrafrecht bezighouden. Waar België en Nederland in diverse opzichten vergelijkbaar zijn en ook een gedeelde geschiedenis hebben, biedt de Belgische aanpak een geheel ander perspectief omdat er daar voor is gekozen om jeugdstrafzaken buiten het strafrecht om af te handelen.

Goedseels voert ons in het eerste hoofdstuk mee in de keuzes die de Belgische wetgever in de afgelopen eeuw heeft gemaakt. Ze laat zien hoe jeugdigen die 'een als misdrijf omschreven feit' (MOF) hadden begaan, in 1912 onder de wet op de kinderbescherming werden gebracht. Hun delinquent gedrag werd in de eerste plaats gezien als een symptoom van een tekort in de opvoeding, dat met het oog op de bescherming van de maatschappij via beschermingsmaatregelen moest worden aangepakt. Volgens Goedseels kwam het beschermingsmodel in 1965 volledig tot bloei toen het toepassingsbereik van de wet werd uitgebreid naar jongeren in een 'problematische opvoedingssituatie'(POS). Aan beide groepen jeugdigen, of ze nu via een MOF of een POS met de jeugdrechter in aanraking komen, kunnen dezelfde maatregelen van bewaring, behoeding en opvoeding worden opgelegd.

Een centraal onderwerp in het proefschrift is de keuze van de wetgever voor bepaalde jeugdrechtmodellen en de wijze waarop daar in de praktijk mee wordt omgegaan. Dit is vanwege de hiervoor genoemde keuze voor het beschermingsmodel een typisch Belgische discussie. In het proefschrift wordt beschreven hoe dit beschermingsmodel in de jaren zeventig onder druk kwam te staan vanwege o.a. de grote macht van de jeugdrechter en de gebrekkige rechtswaarborgen. Er kwam een 'modellendiscussie' op gang waarbij er zelfs sprake zou zijn van verdeeldheid tussen de Nederlands- en Franstaligen. De Nederlandstaligen zouden meer in een sanctionerend rechtswaarborgenmodel zien, terwijl de Franstaligen zouden willen vasthouden aan het beschermingsmodel. Uiteindelijk is in de Belgische Jeugdwet van 2006 het beschermingsmodel behouden, maar aangevuld met elementen uit andere jeugdrechtmodellen. Het feit dat het modellendebat hiermee verschoof van de wetgever naar de rechter, vormde voor Goedseels de 
belangrijkste aanleiding om die beslissingspraktijk te onderzoeken (hoofdstuk V). Dit onderzoek wordt voorafgegaan door onderzoek naar jeugdrechtmodellen in de literatuur (hoofdstuk II), naar de wijze waarop ze in de Belgische Jeugdwet tot uitdrukking komen (hoofdstuk III), en een verkenningstocht door het sentencinglandschap (hoofdstuk IV).

De definitie die Goedseels gebruikt voor een jeugdrechtmodel is dat het een samenhangend geheel is van opvattingen over jeugdcriminaliteit, de plegers en de aanpak daarvan in de vorm van een ideaaltypische vereenvoudigde voorstelling van de realiteit. Uit haar studie naar het gebruik van jeugdrechtmodellen in de literatuur komt naar voren dat deze dienst doen om systemen te kunnen vergelijken, om ontwikkelingen door de tijd heen te beschrijven, om in empirisch onderzoek de onderliggende visies van professionals te duiden of om vanuit een normatief-theoretisch perspectief een bepaald jeugdrechtmodel te verdedigen. Uit haar verkenning blijkt tevens dat het vanouds gemaakte onderscheid tussen het beschermingsmodel (welfare) aan de ene kant en het strafmodel (justice) aan de andere kant te beperkt is en veel auteurs meer modellen onderscheiden. Goedseels komt op basis van in de literatuur onderscheiden criteria die gerelateerd zijn aan daderkenmerken, kenmerken eigen aan de maatregel en proceskenmerken tot een eigen typologie van vijf jeugdrechtmodellen (tabel 22 op p. 77). Naast het beschermingsmodel en het strafmodel zijn dat het herstelmodel, het sanctiemodel en het risicomanagementmodel.

Op basis van haar analyse van de Belgische Jeugdwet concludeert Goedseels dat de visie van de wetgever niet consequent de lijn van één jeugdrechtmodel volgt. Allereerst herkent ze het beschermingsmodel in het feit dat delinquent gedrag van de jeugdige nog steeds wordt gezien als een signaal van een onderliggende problematiek. In doelen als het stellen van de norm, bewustmaking van de jeugdige van zijn daden, jeugdigen verantwoordelijk houden voor de gepleegde feiten en aansporen om die verantwoordelijkheid actief op te nemen, herkent ze tevens het sanctiemodel. Het derde model dat ze in de wet herkent, is het herstelmodel, dat naar voren komt uit het uitgangspunt dat prioriteit moet worden gegeven aan herstel en bij de beslissing rekening moet worden gehouden met de schade en de gevolgen voor het slachtoffer. In het doel van de bescherming van de maatschappij en daarop gerichte maatregelen als de jeugdige gevaarlijk gedrag voor hemzelf of voor anderen vertoont en er een kans is op recidive, herkent ze ten vierde het risicomanagementmodel. Tot slot herkent ze er ook het strafmodel in door de focus op de feiten en de rechtswaarborgen.

Het centrale en omvangrijkste deel van het proefschrift is het empirische onderzoek waarvoor gedurende anderhalf jaar kwalitatief onderzoek is verricht onder vijf Nederlandstalige en vijf Franstalige Belgische jeugdrechters. Met betrekking tot 80 door hen behandelde zaken werden de dossiers doorgenomen, de zittingen bijgewoond en de vonnissen bestudeerd. Voor zowel het daderbeeld als de kenmerken van de opgelegde maatregel en de proceskenmerken werd nagegaan welke jeugdrechtmodellen in de praktijk worden gehanteerd. Hier kan slechts worden volstaan met enkele algemene bevindingen, waaronder die dat het beschermingsmodel het meest dominant aanwezig is. De focus is gericht op de jeugdige en zijn 
onderliggende problemen en de maatregelen zijn gericht op hulp, bescherming, behandeling of opvoeding, zolang dat volgens de jeugdrechter nodig is. Daarnaast wordt het sanctiemodel gehanteerd doordat jeugdrechters het als hun taak zien een duidelijk signaal te geven dat bepaald gedrag in de samenleving niet wordt getolereerd, en zo een norm te stellen en de jongere tot inzicht te brengen. Het strafmodel komt tot uitdrukking doordat jeugdigen tijdens de zitting steeds opnieuw worden herinnerd aan wat hun te wachten staat als ze zich niet aan de opgelegde maatregelen of voorwaarden houden en zich zo blijven gedragen. Het risicomanagementmodel speelt een rol doordat jeugdrechters steeds de kans op recidive afwegen. Opvallend is de bevinding dat het herstelmodel, waar België naam mee heeft gemaakt, in de praktijk van de Belgische jeugdrechters afwezig lijkt te zijn. Het vergoeden van de schade gebeurt hoogstens aan het einde van de rit, wanneer de zaak gedagvaard wordt en het slachtoffer zich burgerlijke partij kan stellen. Het gaat dan echter niet om een herstelrechtelijk proces waarin het delict terug in handen van de betrokken actoren gegeven wordt en er ruimte is voor de beleving en betekenisgeving van zowel het slachtoffer als de jeugdige dader.

Het door Goedseels aangereikte instrument van de modellen vraagt erom om daarmee kort ook de ontwikkelingen in het Nederlandse jeugdstrafrecht te analyseren. Ook de Nederlandse aanpak van jeugdcriminaliteit werd vanaf 1905 beheerst door het beschermingsmodel, niet door het jeugdstrafrecht onder het jeugdbeschermingsrecht te brengen, maar door het gelijktijdig en in nauw verband met het jeugdbeschermingsrecht in te voeren. De minister achter deze Kinderwetten, Cort van der Linden, wees daartoe op het verband tussen verwaarlozing in de opvoeding en het plegen van strafbare feiten. Deze destijds nieuwe opvattingen waren in Nederland geïntroduceerd door de Belgische minister van Justitie Le Jeune, die in 1891 rijksweldadigheidsscholen had ingevoerd in België, waar zwervende en bedelende kinderen konden worden geplaatst die lichte strafbare feiten hadden gepleegd (Nijland, 1895). Tijdens de parlementaire behandeling van de Strafrechtelijke Kinderwet werd Le Jeune zelfs 'de vader' van ons nieuwe stelsel genoemd. ${ }^{1}$ In 1965 werd het jeugdstrafrecht nog verder aangepast aan het jeugdbeschermingsrecht en het beschermingsmodel, maar kort daarna werd ook in Nederland, net als in België, kritiek geuit op de grote macht van de kinderrechter en aandacht gevraagd voor rechtswaarborgen. Mede als gevolg daarvan werd het jeugdstrafrecht bij de herziening van 1995 aangepast aan het strafmodel van het volwassenenstrafrecht en verloor het veel van zijn specifieke kenmerken. Dat is veranderd sinds de ontwikkeling van specifiek beleid rond jeugdcriminaliteit, met name op basis van het Actieprogramma voor de aanpak van jeugdcriminaliteit 2003-2006 'Jeugd Terecht'. Daarmee werd het risicomanagementmodel geïntroduceerd, dat verder is doorgevoerd dan in het Belgische jeugdrecht. Er worden risicotaxaties gemaakt en er mogen alleen gedragsinterventies worden toegepast waarvan is bewezen dat ze effectief zijn in het tegengaan van specifieke risicofactoren. Interessant genoeg leidt deze aandacht voor de oorzaken van criminaliteit tot een gezinsgerichte aanpak, die inhoudelijk gezien 
steeds meer karaktertrekken vertoont van het oorspronkelijke beschermingsmodel van Cort van der Linden (Uit Beijerse, 2017).

Een opvallend verschil met de Belgische situatie, zoals die is beschreven in het proefschrift, is dat ouders in België, anders dan in Nederland, niet verplicht zijn om de zitting bij te wonen, maar als ze er zijn een grotere rol lijken te spelen. Ze zouden zelfs het woord nemen voor de jeugdige tijdens de behandeling van de zaak, wat in Nederland is uitgesloten. Dat hangt waarschijnlijk samen met het feit dat het geen strafzaak is, maar een maatregel van jeugdbescherming, en dat jeugdigen in België, zoals dat in Nederland het geval was tot 1995, worden berecht door hun 'eigen' jeugdrechter, die in alle fasen van de procedure is betrokken en ook toezicht houdt op de tenuitvoerlegging van maatregelen. Dat betekent dat deze rechter de jeugdige en zijn ouders beter zal kennen dan in Nederland het geval is.

Goedseels sluit het proefschrift af met de conclusie dat in bredere kring zou moeten worden gereflecteerd op de principes die aan de Belgische Jeugdwet ten grondslag zouden moeten liggen, op de na te streven doelen en op de middelen om deze doelen te bereiken. Deze aanbeveling is ook relevant voor de Nederlandse jeugdwetgeving, die het afgelopen decennium zoveel ingrijpende wijzigingen met verschillende doelen heeft ondergaan dat ook daar geen duidelijk model meer in te herkennen is. Daarnaast bieden de in het proefschrift onderscheiden jeugdrechtmodellen als vereenvoudigde voorstellingen van de werkelijkheid, zoals hiervoor al bleek, een handzaam instrument om rechtssystemen te analyseren, te vergelijken of ontwikkelingen in de tijd te beschrijven. Een persoonlijke kanttekening plaats ik bij de suggestie om deze modellen als leidraad te laten dienen voor de wetgever. Dat het beschermingsmodel in de praktijk vaak gepaard gaat met weinig rechtswaarborgen, betekent mijns inziens niet dat beide onverbrekelijk met elkaar zijn verbonden. De uitdaging en opdracht voor de wetgever ligt juist daarin om een aanpak gericht op opvoeding en bescherming hand in hand te laten gaan met wettelijke garanties en rechtswaarborgen. Dat is ook wat internationale en Europese kinderrechtennormen van de wetgeving en praktijk verlangen, of een land nu een systeem heeft dat jeugdstrafzaken afhandelt via het jeugdstrafrecht of via het jeugdbeschermingsrecht.

\section{Literatuur}

Beijerse, J. uit (2017). Jeugdstrafrecht. Beginselen, wetgeving en praktijk. Antwerpen: Maklu. Nijland, M.C. (1895). Rijksweldadigheidsscholen in België (diss. Utrecht). Utrecht: P. den Boer. 